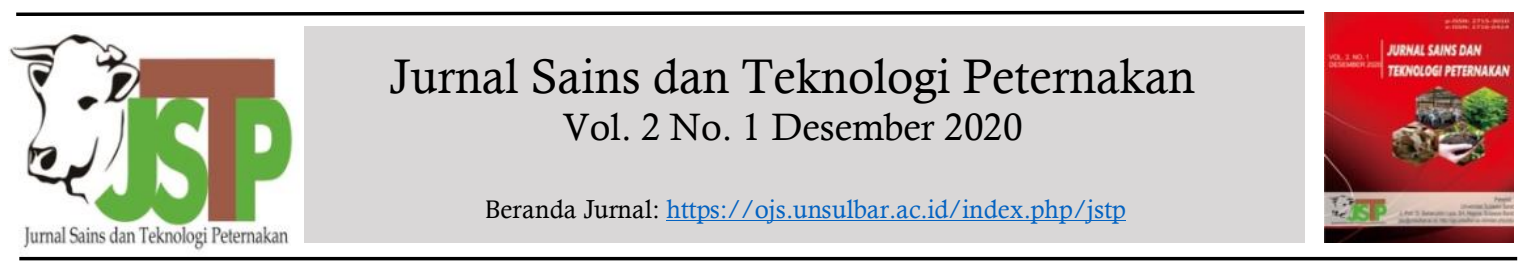

\title{
Pengaruh Pupuk Organik Cair dengan Konsentrasi Urin dan MOL Berbeda terhadap Produksi Rumput Gajah Mini (Pennisetum purpureum cv. Mott)
}

(Effect of Liquid Organic Fertilizer with Different Urine and LMO Concentrations on Mini Elephant Grass Production (Pennisetum purpureum cv. Mott)

Fitriana Akhsan ${ }^{1^{*}}$, Sukriandi ${ }^{1}$, A. Fajar Kurniawan Amris ${ }^{1}$, Muh. Irmansyah ${ }^{1}$

${ }^{1}$ Program Studi Agribisnis Peternakan, Jurusan Peternakan, Politeknik Pertanian Negeri Pangkajene Kepulauan. J1. Poros Makassar-Pare, KM. 83, Pangkep 90655.

A R T I CLE INFO

Received: 29 September 2020

Accepted: 8 Januari 2021

*Corresponding author fitriana.akhsan@yahoo.com

Keywords:

Liquid organic fertilizer Local microorganism (LMO) Mini elephant grass

Kata Kunci:

Mikroorganisme lokal (MOL) Pupuk organik cair (POC) Rumput gajah mini

\begin{abstract}
A B S T R A C T
Liquid organic fertilizer with the right concentration is expected to be a source of nutrients for the growth of mini elephant grass. The aims of this study were to determine the effect of liquid organic fertilizer with different concentrations of urine and Local Microorganism (LMO) on the production of mini elephant grass. The research method used was a randomized block design (RBD) with 4 treatments and each treatment consisted of 3 groups as replications. The treatments used were liquid organic fertilizer, with concentrations of P0 (as a control), P1 (100\% urine, $0 \%$ LMO), P2 (90\% urine, $10 \%$ LMO) and P3 (85\% urine, $15 \%$ LMO). The results showed that liquid organic fertilizer with different concentrations of urine and MOL had no significant effect on plant height, number of leaves, number of tillers and production of fresh weight (g/clump). The liquid organic fertilizer with different urine and MOL concentrations has no significant effect on the growth and production of mini elephant grass.
\end{abstract}

\section{A B S T R A K}

Pupuk organik cair (POC) dengan konsentrasi tepat diharapkan mampu menjadi sumber hara bagi pertumbuhan rumput gajah mini. Tujuan penelitian ini yaitu mengetahui pengaruh POC dengan konsentrasi urin dan mikroorganisme lokal (MOL) yang berbeda terhadap produksi rumput gajah mini. Metode penelitian yang digunakan adalah rancangan acak kelompok (RAK) dengan 4 perlakuan dan setiap perlakuan terdiri dari 3 kelompok sebagai ulangan. Perlakuan yang digunakan adalah pemberian POC, dengan konsentrasi P0 (kontrol), P1 (100\% urin, $0 \%$ MOL), P2 (90 $\%$ urin, $10 \%$ MOL) dan P3 (85 \% urin, $15 \%$ MOL). Hasil penelitian menunjukkan bahwa POC dengan konsentrasi urin dan MOL yang berbeda tidak memberikan pengaruh nyata terhadap tinggi tanaman, jumlah daun, jumlah anakan dan produksi berat segar (g/rumpun). Pemberian POC dengan konsentrasi urin dan MOL berbeda tidak berpengaruh nyata bagi pertumbuhan dan produksi rumput gajah mini. 


\section{Pendahuluan}

Hijauan makanan ternak merupakan pakan utama bagi ternak ruminansia. Hijauan makanan ternak mengandung protein, energi dan serat yang sangat dibutuhkan oleh ternak ruminansia, sehingga memiliki peranan penting dalam memenuhi kebutuhan hidup pokok (maintenance), produksi, dan reproduksi ternak. Rumput gajah mini merupakan jenis rumput berkulitas yang digunakan sebagai pakan ternak ruminansia. Rumput gajah mini (Pennisetum purpureum cV. Mott) merupakan jenis rumput unggul yang mempunyai produktivitas tinggi. Rumput gajah mini merupakan rumput yang mampu beradaptasi pada kondisi lahan yang memiliki tingkat kesuburan rendah dan tanggap terhadap pemupukan.

Upaya peningkatan produksi hijauan pada lahan marginal dapat dicapai dengan melakukan intensifikasi pertanian melalui pemupukan yang ramah lingkungan, yaitu dengan penggunaan pupuk organik (Muhakka, Napoleon, \& Rosa, 2012). Pupuk organik merupakan jenis pupuk yang mampu merevitalisasi produktivitas tanah karena tidak menghasilkan residu negatif bagi tanah dalam jangka panjang sehingga menjadi solusi utama dalam menjaga kualitas tanah guna meningkatkan produksi hijauan.

Salah satu pupuk organik yang dapat digunakan adalah pupuk organik cair (POC) yang berasal dari urin ternak dan campuran mikroorganisme lokal (MOL) dari fermentasi limbah pertanian. Kelebihan POC yaitu penyedia unsur hara makro $(\mathrm{N}, \mathrm{P}, \mathrm{K}, \mathrm{Ca}, \mathrm{Mg}$ dan $\mathrm{S})$ dan mikro ( $\mathrm{Zn}, \mathrm{Cu}, \mathrm{Mo}, \mathrm{Co}, \mathrm{B}, \mathrm{Mn}$ dan $\mathrm{Fe}$ ) (Jasmidi, Zainuddin M, \& Prastowo, 2018). POC memegang peranan penting dalam metabolisme dan sebagai penentu kualitas hijauan. (Muhakka et al. (2012) melaporkan hasil penelitian bahwa pemberian POC 2 liter/ha dapat meningkatkan produksi segar dan berat kering yang optimal pada rumput gajah Taiwan. Mikroorganisme lokal merupakan kumpulan berbagai jenis mikroorganisme yang dapat dibudidayakan dan dijadikan sebagai starter dalam pembuatan pupuk organik yang berbahan baku limbah pertanian dan kotoran ternak (Juanda, Irfan, \& Nurdiana, 2011). Pemberian MOL maupun pupuk organik padat diharapkan mampu memelihara kesuburan tanah, meningkatkan populasi mikroba tanah serta menjaga kelestarian lingkungan (Wiswasta, Widnyana, Raka, \& Cipta, 2016). Mikroorganisme lokal mengandung zat pengatur tumbuh sitokinin yang membantu mempercepat pembelahan sel, mengandung lebih banyak mikroba, bahannya mudah didapat dan tidak berbau busuk (Lestari, Nurbaiti, \& Khoiri, 2014).

POC berbahan dasar urin yang telah difermentasi menggunakan mikrooganisme lokal merupakan campuran dari mikroba yang mampu meningkatkan kandungan fosfor dan kalium bagi tanaman. Peningkatan tersebut dicapai dengan adanya bantuan mikroba-mikroba yang terbukti mampu bekerjasama meningkatkan pertumbuhan tanaman (Hanafi, Rahmawati, \& Sadeli, 2019).

Diperlukan bahan-bahan pembuat berupa urin dan MOL dengan konsentrasi yang tepat untuk menghasilkan POC yang berkualitas. POC dengan konsentrasi tepat diharapkan mampu menjadi sumber hara bagi pertumbuhan rumput gajah mini. Penelitian ini dilaksanakan dengan tujuan untuk mengetahui pengaruh POC dengan konsentrasi urin dan MOL berbeda terhadap produksi rumput gajah mini dan menetukan konsentrasi urin dan MOL dalam pembuatan POC yang paling optimal untuk produksi rumput gajah mini.

\section{Materi dan Metode}

\subsection{Tempat dan Waktu Penelitian}

Penelitian ini dilaksanakan di kebun rumput Kelurahan Attangsalo, Kecamatan Ma'rang, Kabupaten Pangkep, Sulawesi Selatan. Waktu penelitian dilaksanakan pada bulan April hingga Juni 2020.

\subsection{Materi Penelitian}

Alat yang digunakan dalam penelitian ini adalah cangkul, ember, sekop kecil, sabit, alat penyiram tanaman, meteran, gelas ukur, kamera, toples, timbangan, gunting, lakban, jirigen dan saringan. Bahan yang digunakan dalam penelitian ini adalah urin sapi, MOL (air cucian beras, limbah pasar berupa pisang, wortel, tomat dan kol busuk, serta gula merah) dan sobekan rumpun rumput gajah mini.

\subsection{Rancangan Percobaan}

Penelitian ini dilaksanakan dengan metode Rancangan Acak Kelompok (RAK) dengan 4 perlakuan dan setiap perlakuan terdiri dari 3 kelompok sebagai ulangan. Perlakuan yang digunakan adalah POC dengan bahan pembuatan yaitu urin dan MOL dengan konsentrasi sebagai berikut: P0 (0\% urin, $0 \%$ MOL sebagai kontrol), P1 (100\% urin, $0 \%$ MOL), P2 (90\% urin, $10 \%$ MOL), P3 (85\% urin, $15 \% \mathrm{MOL})$. 


\subsection{Prosedur Penelitian}

POC dibuat dengan mencampurkan urin dan MOL yang sudah difermentasi selama 7 hari dengan menggunakan limbah sayuran dan limbah dapur sesuai dengan konsentrasi yang telah ditentukan sebelumnya. Setelah tercampur, pupuk difermentasi selama 7 hari sebelum disemprotkan pada rumput gajah mini. Pupuk cair diberikan setiap seminggu sekali dengan cara disemprotkan pada tanaman, perbandingan antara POC dengan air adalah 1:5. Pupuk cair disemprotkan sebanyak $120 \mathrm{ml} /$ petak $\left(10 \mathrm{~m}^{2}\right)$. Penyemprotan dilakukan di bagian tanaman seperti daun dan batang untuk mempercepat proses penyerapan. Penyemprotan dilakukan sesuai dengan arah mata angin agar pupuk cair yang disemprotkan tidak mempengaruhi petak percobaan lain yang memiliki perlakuan berbeda.

Penanaman rumput gajah mini dengan jarak $50 \times 50 \mathrm{~cm}$. Bahan tanam yang digunakan adalah sobekan rumpun. Pemotongan dilakukan 30 hari setelah tanam (HST) dengan meninggalkan batang $10 \mathrm{~cm}$ dari permukaan tanah.

\subsection{Peubah yang Diamati}

Peubah yang diamati adalah tinggi tanaman, jumlah daun (lembar), jumlah anakan (batang) dan produksi berat segar (g/rumpun).
Produksi berat segar diperoleh dengan cara menimbang berat segar masing-masing perlakuan (Wadi, Darmawan, Harifuddin, Irwan, \& Akhsan, 2020) pada saat defoliasi umur $30,37,44,51$, dan 58 hari.

\subsection{Analisis Data}

Data yang diperoleh diuji dengan analisi sidik ragam (ANOVA) dengan bantuan software SPSS Ver. 16,0. Apabila data yang diuji memperlihatkan pengaruh nyata, maka akan dilanjutkan dengan uji wilayah berganda Duncan (Gaspersz, 1991).

\section{Hasil dan Pembahasan}

\subsection{Pertambahan Tinggi Tanaman}

Tinggi tanaman merupakan salah satu parameter yang digunakan untuk mengetahui pertumbuhan vegetatif tanaman. Proses pertumbuhan tanaman dipengaruhi oleh beberapa faktor yaitu diantaranya lingkungan, fisiologis dan genetika tanaman. Berdasarkan hasil pengukuran tinggi tanaman yang dilakukan sebanyak 5 kali dengan interval 7 hari. Hasil pengukuran tinggi tanaman dapat dilihat pada Tabel 1. Tabel 1 menunjukkan pertumbuhan tinggi tanaman rumput gajah mini yang diberi POC dengan konsentrasi urin dan MOL yang berbeda.

Tabel 1. Pertumbuhan tinggi tanaman rumput gajah mini dengan pemberian POC dengan konsentrasi urin dan MOL yang berbeda

\begin{tabular}{lccccc}
\hline \multirow{2}{*}{ Perlakuan } & \multicolumn{5}{c}{ Tinggi tanaman $(\mathrm{cm})$} \\
\cline { 2 - 5 } & Pemotongan 1 & Pemotongan 2 & Pemotongan 3 & Pemotongan 4 & Pemotongan 5 \\
\hline P0 & $49,10 \pm 1,57$ & $62,47 \pm 7,00$ & $61,46 \pm 5,06$ & $69,22 \pm 9,21$ & $72,67 \pm 7,31$ \\
P1 & $43,98 \pm 8,24$ & $52,29 \pm 5,81$ & $49,59 \pm 5,87$ & $56,24 \pm 6,83$ & $63,26 \pm 10,41$ \\
P2 & $47,48 \pm 5,22$ & $56,88 \pm 9,42$ & $57,00 \pm 6,52$ & $65,18 \pm 11,49$ & $74,32 \pm 17,28$ \\
P3 & $52,39 \pm 2,89$ & $58,02 \pm 15,68$ & $59,07 \pm 9,55$ & $70,21 \pm 10,63$ & $75,36 \pm 16,24$ \\
\hline
\end{tabular}

Keterangan: P0 (0 \% urin, 0 \% MOL sebagai Kontrol), P1 (100 \% urin, 0 \% MOL), P2 (90 \% urin, $10 \%$ MOL), P3 (85\% urin, $15 \%$ MOL).

Secara umum tinggi tanaman yang diperoleh lebih rendah daripada penelitian yang dilakukan oleh Wadi, Darmawan, Harifuddin, Hasyim, et al. (2020) yang menyatakan bahwa tinggi tanaman rumput gajah mini berkisar antara $80-130 \mathrm{~cm}$. Perbedaan ini diduga disebabkan oleh pemberian dosis pupuk yang tidak tepat.

Respon pertumbuhan pada penelitian ini tidak sesuai dengan hasil yang dilaporkan oleh Syamsuddin (2016) bahwa pemberian POC yang memberikan respon terbaik terhadap pertumbuhan rumput gajah mini pada lahan kritis yaitu dengan dosis $120 \mathrm{ml} / 10 \mathrm{~m}^{2}$. Pemberian dosis yang tidak sesuai, memberikan pengaruh terhadap pertumbuhan rumput gajah menjadi kurang optimal, disebabkan karena perlakuan tersebut belum mampu meningkatkan unsur hara tanah sehingga tanaman kekurangan unsur hara untuk proses pertumbuhan. Perbedaan tersebut juga disebabkan lahan yang digunakan dalam penelitian tergolong lahan kering-kritis. Unsur hara yang terkandung di dalam lahan kritis tergolong rendah. Selain hal tersebut, karakteristik dari pupuk organik memerlukan waktu yang relatif lama untuk diserap oleh tanaman dibandingkan dengan pupuk anorganik.

Pemeliharaan rumput gajah mini yang dilakukan pada penelitian ini hanya dilakukan 
dalam waktu sebulan, sehingga unsur hara dalam POC belum terserap maksimal, sehingga efek dari POC tersebut tidak terlihat. Menurut Parnata (2010) kelemahan pupuk organik yaitu kecepatan penyerapan unsur hara oleh tanaman lebih lama dibandingkan dengan penyerapan unsur hara dari pupuk anorganik. Faktor yang mempengaruhi tingkat pertumbuhan tanaman adalah faktor internal dan eksternal. Secara internal kualitas stek dan waktu antara pemotongan bibit dengan penanaman, sedangkan faktor eksternal berupa suhu, kelembaban, media tanam, hormonal, sinar matahari dan air (Mufarihin et al., 2012).

\subsection{Jumlah Daun}

Jumlah daun rumput gajah mini yang diberikan POC dengan konsentrasi urin dan mol yang berbeda dapat dilihat pada Tabel 2 . Pengukuran jumlah daun pada rumput gajah mini dilakukan sebanyak 4 kali dengan interval 7 hari sekali. Pengukuran dilakukan dengan menghitung jumlah daun yang ada di indukan rumput gajah mini. Haryadi, Yetti, \& Yoseva (2015) menyatakan bahwa jumlah daun yang dihasilkan akan berpengaruh terhadap produksi berat segar tanaman.

Uji sidik ragam menunjukkan bahwa pengukuran jumlah daun tidak menunjukkan pengaruh yang nyata $(\mathrm{P}>0.05)$ (Tabel 2). Penyerapan unsur hara dari pupuk organik membutuhkan waktu yang relatif lama. Hasil penelitian ini menunjukkan bahwa pengaruh pemberian POC berbahan dasar urin dan MOL belum bisa terlihat pada umur 1 bulan setelah penanaman. Berbeda dengan penggunaan pupuk feses sapi pada penelitian yang dilakukan oleh Sulaiman, Dwatmadji, \& Suteky (2018) yang menunjukkan bahwa parameter produksi rumput odot mulai terlihat pengaruhnya pada umur 4 pekan setelah penanaman

Tabel 2. Jumlah daun rumput gajah mini dengan pemberian POC dengan konsentrasi urin dan MOL yang berbeda

\begin{tabular}{lcccc}
\hline \multirow{2}{*}{ Perlakuan } & \multicolumn{4}{c}{ Jumlah Daun (lembar) } \\
\cline { 2 - 5 } & Pemotongan 1 & Pemotongan 2 & Pemotongan 3 & Pemotongan 4 \\
\hline P0 & $3,33 \pm 0,33$ & $4,39 \pm 0,10$ & $5,83 \pm 0,29$ & $7,06 \pm 0,48$ \\
P1 & $3,11 \pm 0,77$ & $4,28 \pm 1,11$ & $5,22 \pm 1,11$ & $7,67 \pm 1,53$ \\
P2 & $3,72 \pm 0,95$ & $4,61 \pm 1,13$ & $6,17 \pm 1,04$ & $8,33 \pm 1,15$ \\
P3 & $3,67 \pm 0,33$ & $5,00 \pm 0,33$ & $6,67 \pm 0,58$ & $8,22 \pm 0,38$ \\
\hline
\end{tabular}

Keterangan: P0 (0 \% urin, 0 \% MOL sebagai Kontrol), P1 (100\% urin, $0 \%$ MOL), P2 (90 \% urin, $10 \%$ MOL), P3 (85\% urin, $15 \%$ MOL).

Pengaruh perlakuan tidak terlihat pada penelitian ini menunjukkan belum terserapnya hara yang ada pada POC. Faktor pembatas pertumbuhan dan produksi tanaman di daerah tropis adalah ketersediaan nitrogen (Hanafi et al., 2019). Panggabean \& Wardati (2015) menyatakan bahwa tanaman akan tumbuh subur jika unsur hara yang dibutuhkan tanaman tersedia dalam jumlah yang cukup dan dapat diserap oleh tanaman. Tersedianya unsur hara maka dapat merangsang tanaman untuk menyerap unsur hara lebih banyak serta merangsang fotosintesis.

Lahan yang digunakan pada penelitian ini tergolong lahan kering-kritis, dimana unsur hara yang terkandung didalamnya sangat rendah. Oleh karena itu dibutuhkan waktu lebih dari 1 bulan untuk menyerap unsur hara. Apabila lahan kering kritis tidak dipupuk maka tanaman yang tumbuh di dalamnya akan semakin terhambat pertumbuhannya, sehingga semakin rendahnya persentase unsur hara yang tersedia, maka kesuburan tanah akan merosot (Kuentz, Ledru, \& Thouret, 2012).
Menurut Nasaruddin (2010) bahwa pemberian pupuk sangat erat kaitannya dengan fase pertumbuhan vegetatif dan generatif. Nitrogen merupakan unsur hara utama bagi pertumbuhan tanaman yang sangat diperlukan untuk pembentukan atau pertumbuhan bagianbagian vegetatif tanaman seperti daun, batang dan akar.

\subsection{Jumlah Anakan dan Produksi Berat Segar}

Pengaruh pemberian POC dengan konsentrasi urin dan MOL yang berbeda terhadap jumlah anakan dan produksi berat segar rumput gajah mini disajikan pada Tabel 3.

Jumlah anakan dan produksi berat segar rumput gajah mini dengan pemberian POC dengan konsentrasi urin dan MOL yang berbeda tidak memberikan pengaruh yang nyata $(\mathrm{P}>0,05)$. Hal ini tidak sesuai dengan penelitian Hanafi et al. (2019) yang menyatakan bahwa jumlah anakan dan produksi berat segar dipengaruhi oleh pemberian pupuk cair urin kambing. Hal tersebut kemungkinan disebabkan oleh pengukuran jumlah anakan dan produksi 
berat segar dilakukan 1 bulan setelah penanaman, sehingga pertumbuhan rumput gajah mini belum optimal.

Tabel 3. Jumlah anakan dan produksi rumput gajah mini dengan pemberian POC dengan konsentrasi urin dan MOL yang berbeda.

\begin{tabular}{lcc}
\hline \multirow{2}{*}{ Perlakuan } & \multicolumn{2}{c}{ Parameter } \\
\cline { 2 - 3 } & $\begin{array}{c}\text { Jumlah anakan } \\
\text { (batang) }\end{array}$ & $\begin{array}{c}\text { Produksi berat segar } \\
(\mathrm{g})\end{array}$ \\
\hline P0 & $0,67 \pm 0,58$ & $25,89 \pm 1,26$ \\
P1 & $0,33 \pm 0,58$ & $23,67 \pm 9,45$ \\
P2 & $1,00 \pm 1,73$ & $32,17 \pm 15,07$ \\
P3 & $1,33 \pm 1,53$ & $32,33 \pm 11,72$ \\
\hline Keterangan: & P0 (0\% urin, 0 \% MOL sebagai Kontrol), P1 \\
& (100\% urin, 0 \% MOL), P2 (90\% urin, 10 \% \\
& MOL), P3 (85 \% urin, 15 \% MOL)
\end{tabular}

Tinggi tanaman berbanding lurus dengan jumlah anakan dan produksi biomassa. Santia, Anis, \& Kaunang (2017) menyatakan bahwa jumlah tunas atau anakan merupakan indikator kemampuan hijauan pakan untuk bertumbuh kembali sekaligus sebagai tanda potensi menghasilkan biomassa yang tinggi. (Hanafi et al. (2019) menyatakan bahwa pupuk organik bisa untuk meningkatkan pertumbuhan tanaman, daun tumbuh lebih hijau, urin ternak yang difermentasi menjadi pupuk akan mempengaruhi anakan tumbuh, semakin banyak bahan organik di tanah semakin banyak anakan tumbuh.

POC berbahan dasar urin telah diketahui mengandung unsur nitrogen yang dibutuhkan oleh tanaman. Kandungan nitrogen tersebut mampu termanfaatkan oleh tanaman dengan penambahan MOL. Penambahan MOL pada POC mempercepat penguraian nitrogen sehingga mampu meningkatkan pertumbuhan anakan dan biomassa rumput gajah mini. Lusiana, Linda, \& Mukarlina (2013) mengemukakan bahwa di dalam urin hewan ternak yaitu sapi dan kambing mengandung zat pengatur tumbuh alami golongan auksin.

\section{Kesimpulan}

Bedasarkan hasil penelitian yang telah dilakukan dapat disimpulkan bahwa POC dengan konsentrasi urin dan MOL yang berbeda tidak memberikan pengaruh yang signifikan terhadap pertumbuhan dan produksi rumput gajah mini.

\section{Ucapan Terima Kasih}

Terima kasih disampaikan kepada Jurusan Peternakan Politeknik Pertanian Negeri Pangkep atas bantuan sarana dan prasarana selama pelaksanaan penelitian.

\section{Daftar Pustaka}

Gaspersz, V. (1991). Metode Rancangan Percobaan. Bandung: CV. Armico.

Hanafi, H. N. D., Rahmawati, N., \& Sadeli, A. (2019). Responden hijauan dengan pemberian urin kambing fermentasi. Jurnal Peternakan Nusantara, 5(1), 21-30.

Haryadi, D., Yetti, H., \& Yoseva, S. (2015). Pengaruh pemberian beberapa jenis pupuk terhadap pertumbuhan dan produksi tanaman kailan (Brassica alboglabra L.). Jom Faperta, 2(2), 1-10.

Jasmidi, Zainuddin M, \& Prastowo, P. (2018). Permanfaatan urin sapi menjadi pupuk organik cair kelompok tani Desa Sukadamai Timur. Jurnal Pengabdian Kepada Masyarakat, 24(1), 570-575. https://doi.org/10.24114/jpkm.v24i1.907 9

Juanda, Irfan, \& Nurdiana. (2011). Pengaruh metode dan lama fermentasi terhadap mutu MOL (mikroorganisme lokal). Jurnal Floratek, 6(2), 140-143.

Kuentz, A., Ledru, M.-P., \& Thouret, J.-C. (2012). Environmental changes in the highlands of the western Andean Cordillera, southern Peru, during the Holocene. Holocene, 22(11), 1215-1226. https://doi.org/10.1177/09596836114097 72

Lestari, D., Nurbaiti, \& Khoiri, M. A. (2014). Pemberian mikroorganisme lokal (MOL) bonggol pisang pada pengomposan jerami padi yang diaplikasikan untuk tanaman padi sawah (Oryza sativa L.) varietas PB-42 dengan metode SRI. Jom Faperta, 1(2), 110. Retrieved from https://jom.unri.ac.id /index.php/JOMFAPERTA/article/view /3694

Lusiana, Linda, R., \& Mukarlina. (2013). Respon pertumbuhan stek batang sirih merah (Piper crocatum Riuz dan Pav) setelah direndam dalam urin sapi. Jurnal Protobiont, 2(2), 157-160.

Mufarihin, A., Lukiwati, D. R., \& Sutarno. (2012). Pertumbuhan dan bobot bahan kering rumput gajah dan rumput raja pada perlakuan aras auksin yang berbeda. Animal Agriculture Journal, 1(2), 1-15.

Muhakka, M., Napoleon, A., \& Rosa, P. (2012). Pengaruh pemberian pupuk cair terhadap produksi rumput gajah Taiwan (Pennisetum 
purpureum Schumach). Jurnal Peternakan Sriwijaya, 1(1), 48-54. https://doi.org/10. 33230/JPS.1.1.2012.1170

Nasaruddin. (2010). Dasar-Dasar Fisiologi Tumbuhan. Makassar: Yayasan Forest Indonesia.

Panggabean, P., \& Wardati. (2015). Pengaruh pupuk organik cair dan pupuk kompos kulit buah kakao terhadap pertumbuhan bibit kelapa sawit (Elaeis gueneensis Jacq.) di pembibitan utama. Jom Faperta, 2(2), 1-11.

Parnata, A. S. (2010). Meningkatkan Hasil Panen dengan Pupuk Organik (1st ed.; Yetty Yulia, Ed.). Jakarta: PT AgroMedia Pustaka.

Santia, Anis, S. D., \& Kaunang, C. L. (2017). Pengaruh tinggi dan jarak waktu pemotongan rumput gajah Dwarf (Pannisetum purpureum cv. Mott ) terhadap pertumbuhan vegetatif dan produksi bahan kering. Jurnal Zootek, 37(1), 116-122. https://doi.org/10.35792/zot. 37.1.2017. 14354

Sulaiman, W. A., Dwatmadji, \& Suteky, T. (2018). Pengaruh pemberian pupuk feses sapi dengan dosis yang berbeda terhadap pertumbuhan dan produksi rumput odot (Pennisetum purpureum cv.Mott) di Kabupaten Kepahiang. Jurnal Sain Peternakan Indonesia, 13(4), 365-376. https: //doi.org/10.31186/jspi.id.13.4.365-376

Syamsuddin, S. N. (2016). Pertumbuhan kembali (regrowth) rumput gajah mini (Pennisetum purpureum cv. Mott) melalui pemberian pupuk organik cair pada lahan kering-kritis. Universitas Hasanuddin, Makassar.

Wadi, A., Darmawan, Harifuddin, Hasyim, H., Akhsan, F., \& Irwan, M. (2020). Effect of the different clipping time on the yield and quality of dwarf napiergrass on marginal land under manure application. IOP Conference Series: Earth and Environmental Science, 492(012021), 1-6. IOP Publishing. https://doi.org/10.1088/1755-1315/492/ $1 / 012021$

Wadi, A., Darmawan, Harifuddin, Irwan, M., \& Akhsan, F. (2020). Pengaruh penggunaan pupuk organik terhadap pertumbuhan rumput gajah mini di lahan kering pada tahun kedua setelah penanaman. Agrokompleks, 20(1), 1-6.

Wiswasta, I. G. N. A., Widnyana, I. K., Raka, I. D. N., \& Cipta, I. W. (2016). Mikroorgansime lokal (MOL) sebagai pupuk organik cair dari limbah pertanian dan kaitannya dengan ketersediaan hara makro dan mikro. Seminar Nasional Hasil Penelitian dan Pengabdian Masyarakat Inovasi IPTEKS Perguruan Tinggi Untuk Meningkatkan Kesejahteraan Masyarakat, (11), 892-900. Denpasar: Lembaga Penelitian dan Pemberdayaan Masyarakat (LPPM) UNMAS. 